\title{
Scripts, Languages, and Authority Control
}

\section{Joan M. Aliprand}

Library vendors' use of Unicode is leading to library systems with multiscript capability, which offers the prospect of multiscript authority records. Although librarians tend to focus on Unicode in relation to non-Roman scripts, language is a more important feature of authority records than script. The concept of a catalog "locale" (of which language is one aspect) is introduced. Restrictions on the structure and content of a MARC 21 authority record are outlined, and the alternative structures for authority records containing languages written in nonRoman scripts are described.

The Unicode Standard is the universal encoding standard for all the charac1 ters used in writing the world's languages. ${ }^{1}$ The availability of library systems based on Unicode offers the prospect of library records not only in all languages but also in all the scripts that a particular system supports. While such a system will be used primarily to create and provide access to bibliographic records in their actual scripts, it can also be used to create authority records for the library, perhaps for contribution to communal authority files.

A number of general design issues apply to authority records in multiple languages and scripts, design issues that affect not just the key hubs of communal authority files, but any institution or organization involved with authority control.

Multiple scripts in library systems became available in the 1980s in the Research Libraries Information Network (RLIN) with the addition of Chinese, Japanese, and Korean (CJK) capability, and in ALEPH (Israel's research library network), which initially provided Latin and Hebrew scripts and later Arabic, Cyrillic, and Greek. ${ }^{2}$

The Library of Congress continued to produce catalog cards for material in the JACKPHY (Japanese, Arabic, Chinese, Korean, Persian, Hebrew, and Yiddish) languages until all of the scripts used to write these languages were supported by an automated system. This requirement was met in 1991, when CJK ideographs, Japanese kana, Korean hangul, and Arabic and Hebrew scripts were all available on RLIN. ${ }^{3}$ (Arabic and Persian are both written in Arabic script; Hebrew and Yiddish are both written in Hebrew script.) The Library of Congress subsequently stopped producing catalog cards for material in the JACKPHY languages.

While non-Roman script data could have been included in authority records on RLIN, two procedural reasons prevented this:

- Unlike bibliographic records, where non-Roman data can just be ignored or discarded when it cannot be handled, all parties working with synchronized authority files have to be able to see authority records in their entirety, including data in non-Roman scripts. Only now, with the increasing use of Unicode in library systems, is the library community achieving this capability.

- In addition, the source of authority for an established heading must be identified, and there may be multiple options for a particular 
language. In the case of controlled Chinese language headings, for example, whose cataloging practice and writing conventions should be followed? Those of mainland China? Of Taiwan? Of Hong Kong?

Librarians tend to look at bibliographic control and access from the perspective of scripts (as suggested by the title of the program at which this paper was presented), but bibliographic control and access really have to do with language. Understanding the two concepts-script and language - is necessary before authority control issues can be considered.

\section{Scripts and Languages}

Text is the visible representation of language. One or more scripts are used to write text. Most scripts are used to write more than one language, as shown in figure 1. A few scripts are used for only one language. Korean hangul and Cherokee are examples. In Japanese writing, several scripts are intermixed-hiragana, katakana, and ideographs (called kanji in Japanese), and even Latin script (romanji).

Language is a fundamental aspect of authority control. The source of authority that defines headings has an explicit or an implied language, and may include instructions on how to coordinate text in other languages - some written in other scripts - with the preferred language of the source of authority.

The Unicode Standard encodes scripts, not languages. The importance of Unicode for authority control, as well as for other aspects of library service, is that Unicode makes creating software that presents text in its proper script easier. Use of Unicode does not provide answers to the most challenging questions related to authority control, languages, and scripts.

\section{Scripts, Languages, and Access Points}

When the access points of bibliographic records are considered in relation to language (which implies script), they fall into three categories: language neutral access points, sourcespecific access points, and locale-specific access points. ${ }^{4}$

Language-neutral access points include standard identification numbers (International Standard Book Number [ISBN], International Standard Serial Number [ISSN], CODEN designation, and so on), the class numbers of a classification scheme, and codes (for example, for language or country of publication). Sources of authority for language neutral access points include:
- technical standards, such as ISO 2108:1992, the International Organization for Standardization publication that defines the ISBN; ${ }^{5}$

- classification schemes, such as the Dewey Decimal Classification System; ${ }^{; 6}$ and

- code lists, such as the MARC code lists. ${ }^{7}$

Note that language-neutral access points are not necessarily script-neutral; for example, the Latin letter $\mathrm{X}$ is used as a check-sum digit in the ISBN, and the highest levels of the Library of Congress classification are designated by letters of the English alphabet.

Language-neutral access points may even reflect the usage of a particular language. MARC language and country codes often reflect the English-language names of languages and countries. The country code for Spain, for example, is "sp" not "es" (for España). Although characters from a particular script may be used in a language-neutral access point, their use is as a symbol or code, not as regular text. The country code "sp," for example, could be rendered as "España" for a Spanishspeaking clientele.

Source-specific access points are straight transcriptions of text from the source of information. In practice, most titles and any notes that are indexed fall into this category.

\begin{tabular}{|l|l|}
\hline Script & Languages written in the script \\
\hline Arabic & $\begin{array}{l}\text { Arabic, Farsi, Pashto, Sindhi, Uighur, Urdu, Ottoman } \\
\text { Turkish, ... }\end{array}$ \\
\hline $\begin{array}{l}\text { Canadian Aboriginal } \\
\text { Syllabics }\end{array}$ & Inuktitut, Cree, ... \\
\hline Cyrillic & Russian, Bulgarian, Ukrainian, .... \\
\hline Devanagari & Hindi, Sanskrit, Awadhi, Newari, Santali, .... \\
\hline Hebrew & Hebrew, Yiddish, Judezmo (Ladino),.... \\
\hline Ideographs & Chinese, Japanese, Korean, historic Vietnamese \\
\hline Latin & English, French, German, Italian, Vietnamese, .... \\
\hline Sinhala & Sinhala, Pali, Sanskrit \\
\hline Thai & Thai, Kuy, Lanna Tai, Pali \\
\hline
\end{tabular}

Figure 1. Scripts and languages_-selected examples

Locale-specific access points include names, uniform titles, subjects, and additional parts of headings in the language of the catalog. These are all access points that consist of headings (or parts of headings) established under authority control. The word "locale" comes from computing, where it refers to the collective features of software that reflect the preferences of users in a particular cultural environment. Sources of authority that determine the 
content of a particular heading include cataloging rules, subject heading lists, and thesauri.

\section{Locale-Specific Access Points}

Locale-specific access points are determined by the needs of users. Each locale determined by a particular set of user requirements must have defined sources of authority to control the creation of headings used as its locale-specific access points.

The basic need of a user is the ability to search the catalog using his or her preferred language, and that language must be written in the proper script. Romanization is not good enough! Aliprand described romanization as "information distortion." "Authority control ensures consistency in access points for a particular language environment. To establish headings in a specific language and script, one must choose a source of authority whose operative language-either explicit or implied —is the language of the catalog user.

Another aspect of locale is the knowledge level of the user. The source of authority must be appropriate for this, as well. The vocabulary for subjects in a catalog must conform to the user's abilities and knowledge. More detailed subject vocabularies meet the needs of experts. Contrast these with a vocabulary to serve children.

Cultural aspects are also part of a locale. Library of Congress subject headings were developed in an American environment, and not all terms have the same meaning throughout the English-speaking world. Language and culture are intertwined and, in some cases, local variation from the norm is necessary. Local terminology could be accommodated by a two-stage searching process:

- initial searching of a locale-specific authority file that contains preferred forms different from those in a general-purpose authority file; and

- searching of the general-purpose file whenever a specific local form was not found.

\section{Multiplicity of Locales}

A specific place or nation may include a number of locales. Language is an important component of a locale. Conceptually, a separate logical catalog exists for each language, with separate authority files for names and subjects. In reality, these may be amalgamated into a single physical catalog, with repetitive data being eliminated. In thinking about multilingual and multiscript access, the catalog must be considered conceptually, that is, as a logical model, not as it is in actuality.

The Anglo-American Cataloging Rules, 2nd ed. (AACR2) and Library of Congress subject headings (LCSH) are accepted so much as basic tools that catalogers may forget that the catalog they are building is for English speakers. ${ }^{9}$ Many of the sources of authority for other languages are based on AACR2 or LCSH, but, despite their origin, they are other sources, used to establish catalog headings in other languages.

Canada, for example, has two official languages, English and French. Conceptually, authority control in Canada serves two locales: English-speaking users and Frenchspeaking users. Because of these multiple service needs, Canada is a leader in multilingual authority control. In its bilingual cataloging policy, Library and Archives Canada stipulates the conditions for establishing both English and French forms of headings used as main or added entries. ${ }^{10}$ For French-language cataloging, the Canadian translation of AACR2, Règles de catalogage anglo-américaines, is used, rather than the descriptive rules used in France. ${ }^{11}$ Holley notes that Canada's French subject headings list, Répertoire de Vedettes-matière (RVM), has been particularly influential internationally. ${ }^{12}$

Canada's Territory of Nunavut, created in 1999, has four official languages: English, French, Inuinnaqtun written in Latin script, and Inuktitut written in Canadian Aboriginal Syllabics. The Canadian Standards Association proposed the addition of the Canadian Aboriginal Syllabics to the Unicode Standard and to its International Standard equivalent, ISO/IEC 10646. ${ }^{13}$ The Association for Library Collections \& Technical Services, Library Information \& Technology Association, and Reference and User Services Association's Machine-Readable Bibliographic Information Committee (MARBI) approved MARBI Proposal 2002-11 in which the Canadian Committee on MARC proposed allowing use of Canadian Aboriginal Syllabics in MARC 21 records encoded in Unicode. ${ }^{14}$

East Asian ideographs present a particularly complex situation in determining what is a language and so what source of authority should control the creation of headings. Different languages (namely, Chinese, Japanese, Korean, and historic Vietnamese) are written entirely or partly with ideographs. In this respect, ideographs are just like any other script that may be used to write multiple languages.

Two writing conventions are used for Chinese: traditional (used in Taiwan and Hong Kong), and simplified (used in the People's Republic of China and in Singapore). What is ostensibly a single language and its script has regional differences. Established headings in Chinese will reflect local writing conventions.

\section{Scripts, Languages, and Authority Formats}

Another item needed for authority control is a specification that defines the structure of the data. Both MARC 21 and UNIMARC (a set of formats for machine-readable data published by the International Federation of Library 
Associations) specify authority formats. Both the MARC 21 and UNIMARC specifications allow use of non-Roman scripts in authority records. The two formats have many data elements in common, although they use different tag designations for them. This paper uses MARC 21 examples.

With respect to the use of non-Roman scripts, the structure of MARC 21 is flexible. MARC 21 allows linking of romanized/non-Roman field pairs (with provision for unlinked non-Roman fields), or the direct use of original scripts in regular fields. These capabilities are present in the MARC 21 Format for Authority Data. ${ }^{15}$

In the UNIMARC Authorities Format, "alternative script representations of the headings, notes, and the tracings may be co-resident in an authority record or may reside in separate linked records."16

The most fundamental requirement for an authority record is that only one established form exists per record. This may seem obvious, but what happens when a person, place, or thing is known by multiple names in different languages and scripts? Should a paired 1XX (heading) field be used for a synonym written in a non-Roman script, the way fields are paired in bibliographic records? This supposition is examined below.

Another requirement for authority records are the $7 \mathrm{XX}$ heading linking entry fields that are essential to maintaining relationships between established forms in other authority files that use different languages, and possibly other scripts. This mechanism provides a basis for interconnected authority files, for which Tillett coined the term "Virtual International Authority File."17

The limitation of one established form per record is imposed by the fact that, in the MARC 21 Format for Authority Data, certain key data elements are singly occurring. Field 008 Fixed-length data elements, which is nonrepeatable, includes two positions that are each only one character long. These data elements, represented by the positions Descriptive cataloging rules and Subject heading system/thesaurus, are both singly occurring.

These two positions specify the sources of authority used to create the record. Position 10, Descriptive cataloging rules, identifies "the descriptive cataloging rules used to formulate the 1XX name, name/title, or uniform title heading in established heading or reference records."18 Position 11, Subject heading system/thesaurus, identifies "the subject heading system/thesaurus building conventions used to formulate the 1XX heading in established heading, reference, subdivision, or node label records." 19

Field 040 subfields e and $\mathrm{f}$ are used if field 008 positions 10 and 11 are inadequate for recording the sources of authority for names and such, and for subjects. Field 040 and subfields e and $f$ are all nonrepeatable.

Each source of authority has an explicit or implied language. Authorized headings in multiple languages cannot be defined in a single record because places to identify the multiple sources of authority for the headings are not available. Each authorized heading in a particular language has to be defined in its own record.

Notice that this limitation applies not just to headings in different scripts or headings in different languages. Headings in the same language, but established according to different sources of authority, cannot be included in the same authority record because there is no way to record the multiple sources of authority.

\section{Structural Aspects of Non-Roman Data in Authority Records}

In bibliographic records, data in the scripts of the source of information and its romanization are contained in a pair of linked fields that may be substituted for each other in certain displays. If the original script cannot be displayed, at least one can see the romanization. When non-Roman scripts are to be included in authority records, should this methodology be replicated?

Aliprand rigorously examined whether romanized and non-Roman fields in authority records should be linked. ${ }^{20}$ Linked field pairs in authority records must be ruled out because one-to-many and many-to-one relationships among data elements often occur. Weinberg independently reached this conclusion. ${ }^{21}$ Examples of one-to-many and many-toone relationships between names in original script and romanized form(s) are given in Weinberg and Aliprand. ${ }^{22}$

Romanized/non-Roman linkage of 1XX fields in an authority record was ruled out above because the structure of authority records provides for only one source of authority for name and for subject. Such linkage must be ruled out in the other fields of an authority record because complex relationships in the data may exist. For example, the Name Authority File (NAF) authority record for Liu, James J. Y. contains three 400 fields. The three see from tracings represent romanizations created from a single name written in ideographs. Application of the ALA-LC conventions for the romanization of Chinese, Japanese, or Korean text to the name written in ideographs yields three different "readings" for the same source name. ${ }^{23}$ The benefit of precluding a single composite authority record with multiple syndetic structures is that such a record would be complicated, and difficult to process and update.

MARC 21 provides for two models of multiscript record: Model A (Vernacular and transliteration) and Model B (Simple multiscript records). ${ }^{24}$ In Model A records, data in the scripts of the source of information appears in the 880 field, Alternate Graphic Representation. Each 880 field is normally paired with the field that contains the romanization of the data in the 880 field. 
This paired methodology was originally developed for bibliographic records. Linked pairs of fields allows romanized data to be substituted for the original scripts when a user prefers to see the romanized form or when a display device is limited to Latin script. Note that unlinked fields containing non-Roman scripts cannot be seen in these circumstances.

In viewing an authority record, however, romanization cannot be substituted for original script data because a cataloger needs to see everything. Pairing of romanized and non-Roman fields in authority records is not needed. Because the complete record must always be seen, whether 880 fields need to be used in authority records is questionable. They might be used internally if software designed for bibliographic records is also used for authority records.

\section{The Name Authority File-Present and Future}

How does this language-oriented view of cataloging work out in reality? Figure 2 shows data from a NAF record as it is today: the extract shows the official names of the United Nations. The names are in languages written in Latin script (English, French, and Spanish) or are romanizations of the names in languages written in other scripts (Russian, Chinese, and Arabic).

The Russian, Chinese, and Arabic names are shown in romanization because not all contributors to the communal NAF have systems that support the scripts of these languages. Notice also that Chinese is shown in pinyin, the current ALA/LC romanization scheme for Chinese, as well as in Wade-Giles, the previous method.

When, in the future, all systems contributing to NAF have multiscript support, two options for an authority record with multiple scripts are possible. Figure 3 shows the minimal approach: all alternative names, including those written in other scripts, are treated as see from tracings in a single record.

Including links to other established headings in the record is also possible; no limitations exist on the scripts that can be used in the "linked to" headings. The 7XX fields, heading linking entry fields, that contain the links have not been included in figure 3 .

The Arabic name of the United Nations (see the last line in figure 3) begins with the definite article. In the romanized form of the Arabic name of the United Nations (see the last line in figure 1 and the fourth line from the bottom in figure 3), the definite article ("al-" in ALA-LC romanization) has been omitted. The definite article is normally ignored in searching and sorting. Because the 410 field does not include an indicator to record the number of initial nonfiling characters, the romanized form of name has been deliberately distorted to obtain the desired result in searching and sorting. Use of more sophisticated searching algorithms in library catalogs or implementation of the recently introduced codes to demarcate nonsorting strings will obviate such crude solutions. ${ }^{25}$

The other option is to have multiple authority files (for example, one for each language) and to link them all together to provide multilingual and multiscript access. This is the concept of the Virtual International Authority File. Figure 4 shows the set of six records establishing "United Nations" in each of its six official languages. For simplicity, links between only two records in the set are shown. Will this approach offer a way to provide multilingual service without having to reinvent the wheel in authority records under our immediate control?

\section{Conclusion}

In theory, any script may be used in authority records. Currently, the NAF and the Subject Authority File controlled by the Library of Congress are limited to Latin script because not all contributors have systems with non-Roman script capability.

\begin{tabular}{|c|c|c|c|}
\hline 110 & 2 & faUnited Nations & English \\
\hline 410 & 2 & faNations Unies & French \\
\hline 410 & 2 & faNaciones Unidas & Spanish \\
\hline 410 & 2 & łaOrganizatsia Ob"edinennykh Natsiì & Russian (ALA-LC) \\
\hline 410 & 2 & faLian he guo & Chinese in Pinyin \\
\hline 410 & 2 & faLien ho kuo & Chinese in Wade-Giles \\
\hline 410 & 2 & łaUmam al-Muttaḥidah & $\begin{array}{l}\text { Arabic }(A L A-L C) \text { with } \\
\text { leading article dropped }\end{array}$ \\
\hline
\end{tabular}

Figure 2. Data from NAF record

\begin{tabular}{|c|c|c|}
\hline 110 & 2 & faUnited Nations \\
\hline 410 & 2 & faNations Unies \\
\hline 410 & 2 & faNaciones Unidas \\
\hline 410 & 2 & łaOrganizatsia Ob"edinennykh Natsii \\
\hline 410 & 2 & $\ddagger$ faLian he guo \\
\hline 410 & 2 & faLien ho kuo \\
\hline 410 & 2 & łaUmam al-Muttahidah \\
\hline 880 & 2 & ‡6410-00а¥аОрганизация Объединенных Наций \\
\hline 880 & 2 & 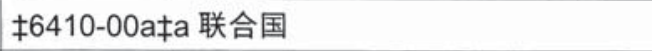 \\
\hline 880 & 2 & الأمم المتحدة †6410-00/rfa \\
\hline
\end{tabular}

Figure 3. See from tracings in true script 


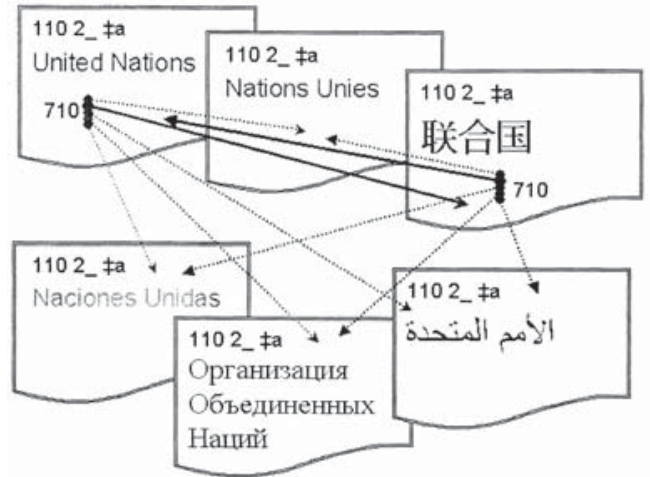

Figure 4. Established headings in true scripts

Logically, authority records should be limited to one authorized heading. When a source of authority specifies or implies a language written in a non-Roman script, the IXX field of the MARC 21 or UNIMARC authority record established under that source of authority will contain that non-Roman script.

Romanized and non-Roman linkage cannot be used in authority records because of the complex relationships in the data of the authority record. All fields in authority records that contain multiple scripts must be unlinked. Therefore, a multiscript MARC 21 Authority record is logically equivalent to Model B (Simple multiscript record).

Authorized headings naming the same entity in different languages or vocabularies should be linked via designated fields in accordance with the Virtual Authority File model. No attempt should be made to force multiple syndetic structures into a single logical record.

Author's note: Unicode is a trademark of Unicode, Inc., and may be registered in some jurisdictions. RLIN and CJK are registered trademarks of $R L G$. Any other trademarks used in this article are the property of their respective owners.

\section{References}

1. Unicode Consortium, The Unicode Standard, Version 4.1.0, Mar. 31, 2005. Accessed June 4, 2005, http://www.unicode. org/versions/Unicode4.1.0.

2. John W. Haeger, "The CJK Enhancements to the RLIN System: A Review of Basic Issues," in Automated Systems for Access to Multilingual and Multiscript Library Materials: Problems and Solutions: Papers from the Pre-conference Held at Nihon Daigaku Kaikan Tokyo, Japan, August 21-22, 1986, edited for the Section on Library Services to Multicultural Populations and the Section on Information Technology by Christine Bossmeyer and Stephen W. Massil (München: Saur, 1987), 156-62; Susan S. Lazinger, “ALEPH: Israel’s Research Library Network: Background, Evolution, and Implications of Networking in a Small Country," Information Technology and Libraries 10 (Dec. 1991): 275-91; Susan S. Lazinger and Judith Levi, "Multiple Non-Roman Scripts in ALEPHIsrael's Research Library Network," Library Hi Tech 14, no. 1 (1996): 111-16.

3. Joan M. Aliprand, “Arabic Script on RLIN," Library Hi Tech 10, no. 4 (1992): 59-80.

4. Joan M. Aliprand, "Multilingual and Multiscript Issues in Cataloguing" (paper presented at the 62nd IFLA General Conference, Beijing, China, 1996). Accessed Feb. 21, 2005, www.ifla.org/IV/ifla62/62-alij.htm.

5. International Organization for Standardization, Information and Documentation - International Standard BookNumbering (ISBN), 4th ed. (ISO 2108:2005) (Geneva: International Organization for Standardization, forthcoming).

6. Dewey Decimal Classification System, OCLC Online Computer Library Center. Accessed Feb. 21, 2005, www. oclc.org/dewey/about/default.htm.

7. Library of Congress, Network Development and MARC Standards Office, "MARC Code Lists," Jan. 13, 2005. Accessed Feb. 21, 2005, www.loc.gov/marc.

8. Joan M. Aliprand, "Nonroman Scripts in the Bibliographic Environment," Information Technology and Libraries 11, no. 2 (June 1992): 105-19.

9. Anglo-American Cataloguing Rules, 2nd ed., 2002 rev. (Ottawa: Canadian Library Association; London: Library Association Publishing; Chicago: ALA, 2002.); Library of Congress, Cataloging Policy and Support Office, Library of Congress Subject Headings, 26th ed. (Washington, D.C.: Library of Congress, Cataloging Distribution Service, 2003).

10. Library and Archives Canada, "Cataloguing and Metadata. Bilingual Cataloguing Policy,” Oct. 19, 2004. Accessed Feb. 21, 2005, www.collectionscanada.ca/6/17/s17-219-e.html.

11. Règles de catalogage anglo-américaines, 2e éd., Rév. de 1988, Élaborées sous la direction de The Joint Steering Committee for Revision of AACR ; rédigées par Michael Gorman et Paul W. Winkler; version française de la révision de 1988 établie par Rachèle Salvador d'après la version française de la deuxième édition établie par Paule-Rolland Thomas avec la collaboration de Pierre Deslauriers (Montréal: ASTED, 1990).

12. Robert P. Holley, "The Répertoire de vedettes-matière de l'Université Laval Library, 1946-92," Library Resources d Technical Services 46, no. 4 (2002): 138-49; "Répertoire de vedettes-matiére (En ligne)," (Québec: Bibliothéque de l'Université Laval, 2002-). Accessed Feb. 21, 2005, www.bibl. ulaval.ca/bd/rvm ("Accès réservé aux membres des établissements autorisés.”) [Also published on CD-ROM (Montréal: Services documentaires multimedia, 1995-).]; Library and Archives Canada, "Répertoire de vedettes-matiére," Jan. 6, 2004. Accessed Feb. 21, 2005, www.collectionscanada. $\mathrm{ca} / \mathrm{rvm} /$ index-e.html.

13. Canadian Standards Association, "Proposed pDAM for Unified Canadian Aboriginal Syllabics," text [by] Dirk Vermeulen and Michael Everson. Unofficial HTML version of the document identified as ISO/IEC JTC 1/SC 2/WG 2 N1441. (Dublin, 1996-08-26). Accessed Feb. 21, 2005, www.evertype.com/standards/sl/n1441-en.html; International Organization for Standardization, Information TechnologyUniversal Multiple-Octet Coded Character Set (UCS) (ISO/ 
IEC 10646:2003), (Geneva International Organization for Standardization, 2003).

14. Canadian Committee on MARC, "Proposal 2002-11: Repertoire Expansion in the Universal Character Set for Canadian Aboriginal Syllabics," May 9, 2002. Accessed Feb. 21, 2005, www.loc.gov/marc/marbi/2002/2002-11.html.

15. Library of Congress, Network Development and MARC Standards Office, MARC 21 Concise Format for Authority Data, 2004 concise ed., Oct. 2004. Accessed Feb. 21, 2005, www.loc.gov/marc/authority.

16. International Federation of Library Associations and Institutions, UNIMARC Manual-Authorities Format 2001 (Concise Version), Jan. 25, 2001. Accessed Feb. 21, 2005, www.ifla.org/VI/3/p2001/guideindex.htm.

17. Barbara B. Tillett, "Authority Control on the Web" (paper presented at Bicentennial Conference on Bibliographic Control for the New Millennium, Jan. 23, 2001). Accessed Feb. 21, 2005, lcweb.loc.gov/catdir/bibcontrol/tillett_paper.html.

18. Library of Congress, Network Development and MARC Standards Office, "008 - Fixed-length Data Elements," in MARC 21 Concise Format for Authority Data, 2004 concise ed. Accessed Feb. 21, 2005, www.loc.gov/marc/authority/ ecadcntr.html\#mrca008.

19. Ibid.

20. Joan M. Aliprand, "Linking of Alternate Graphic Representation in USMARC Authority Records," Cataloging \& Classification Quarterly 18, no. 1 (1993): 27-62.
21. Bella Hass Weinberg, "Hebraic Authorities: A HistoricalTheoretical Perspective," Judaica Librarianship 8 (Spring 1993/Winter 1994): 45-55.

22. Bella Hass Weinberg and Joan M. Aliprand, "Closing the Circle: Automated Authority Control and the Multiscript YIVO Catalog," International Cataloguing and Bibliographic Control 31, no. 3 (July/Sept. 2002): 44-48.

23. Example from Lily Hu, Owen Tam, and Patrick Lo, "Chinese Name Authority Control in Asia: An Overview.” This paper was presented at Authority Control: Definition and International Experiences, an international conference held in Florence, Italy, Feb. 2003. Accessed Feb. 21, 2005, www.sba.unifi.it/ac/ relazioni/lo_eng.pdf.

24. Library of Congress, Network Development and MARC Standards Office, "MARC 21 Concise Authority: Multiscript Records," in MARC 21 Concise Format for Authority Data, 2004 concise ed. Accessed Feb. 21, 2005, www.loc.gov/marc/ authority/ecadmulti.html.

25. Library of Congress, Network Development and MARC Standards Office, "MARC 21 Formats: Guidelines for the Non-Sorting Control Character Technique," Feb. 10, 2004. Accessed Feb. 21, 2005, www.loc.gov/marc/nonsorting.html. 